\title{
Analysing the application of governance principles in the management of COVID-19 in South Africa: Lessons for the future
}

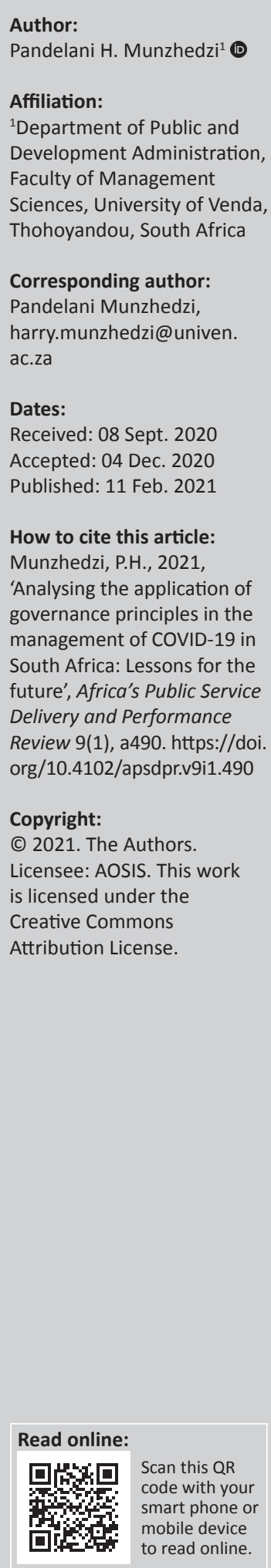

Background: The coronavirus disease 2019 (COVID-19), also known as SARS-CoV-2, poses an enormous challenge to South Africa and the world in as far as its management is concerned. The virus originated in Wuhan City in China at the end of the year 2019 before it spread to other countries of the world. The World Health Organization (WHO) later declared it as a pandemic because of the rapid spread. However, the management of the virus differs from one country to another depending on the systems and principles adopted in that specific country.

Aim: Using relevant literature, this article analyses the application of governance principles in the management of the COVID-19 pandemic in South Africa. The article argues that the application of the governance principles was not adequately adhered to.

Setting: The coronavirus disease 2019 has an effect globally, however, the focus of this article is specifically in South Africa. However, the lessons learnt are not limited to COVID-19 but to other future epidemics.

Methods: The research is qualitative and is based on the vigorous review of relevant literature including relevant reports, regulations and published academic work. Governance theory was adopted to be the lenses within which the reality is viewed.

Results: The article presents lessons that have been learnt from the management of COVID-19 and suggests a balance between a special need to manage pandemics and adherence to standard principles of good governance to ensure accountability in the use of state resources whilst ensuring effective management of a disaster.

Conclusion: It is imperative that there is an adherence of relevant policies regulating public procurement of goods and services. This is due to the fact that procurement policies make provision for procurement in instances where open bidding process may not be followed including during the time of disaster. Necessary inputs from relevant stakeholders need to be sought for a proper collaboration and support from them and the society at large.

Keywords: COVID-19; governance; participation; procurement; management.

\section{Introduction}

Governance is recognised by many scholars and practitioners alike as a solution to world developmental challenges including but not limited to poverty, unemployment and inequality (Helalo 2015; Khalil-Babatunde 2014; Munzhedzi \& Makwembere 2019). The coronavirus disease 2019 (COVID-19), which is also a coronavirus, is a respiratory virus that poses a major developmental challenge as a result of the fact that most economies in the world were on lockdown from the first quarter of 2020. Some economies, including that of South Africa, are partially unlocked in terms of lockdown regulations and guidelines. The coronavirus disease 2019 was first reported on the 31st of December 2019 by the World Health Organization (WHO) to have originated in the Wuhan City, Hubei province in China (Dong, Hu \& Gao 2020; WHO 2020). It is spread from one person to another through respiratory droplets, which are produced mainly when a person with the infection coughs or sneezes, and they are in close contact (less than $1.5 \mathrm{~m}$ ). Those who are older than 60 years and people with underlying medical conditions such as HIV, cardiovascular disease, diabetes, chronic respiratory disease and cancer are at risk of getting sick without the possibility of recovery from the virus (Dong et al. 2020). South Africa diagnosed its first COVID-19 case on 05 March 2020, and thereafter the President declared a state of national disaster on 15 March 2020, followed by the lockdown from the 26th of the 
same month. The coronavirus disease 2019 has brought with it developmental challenges to countries of the world including South Africa. Employment opportunities have reduced in that small and medium enterprises such as hair salons, restaurants and theatres have been closed in level five and four of the lockdown. Some have since been opened with the relaxation of lockdown level three (level three commenced on 01 June 2020).

The pandemic and the subsequent lockdown in the context of South Africa pose an enormous challenge for the socioeconomic well-being of the country and her people. The good application of governance principles may adequately address development challenges including the COVID-19 pandemic in South Africa. This article analyses the application of governance principles in the management of the COVID-19 pandemic in South Africa. The analysis is undertaken through the review of existing literature and reports on governance-related matters. Literature related to the topic was grouped together based on themes being addressed and reviewed to determine the applicability of governance principles during the management of the pandemic. The ensuing section of the article conceptualises governance and discusses the relevant theoretical framework.

\section{Conceptualisation and theoretical framework}

The concept of governance in politics and development is arguably as old as human history (Matshabaphala 2015:497). but it has gained momentum in recent years throughout the world (Khalil-Babatunde 2014). However, scholars and practitioners alike have not reached a consensus about the meaning although it is safe to say that there are certain common elements that are found in most definitions. Whilst government is more about bureaucracy, legislation, financial control, regulation and force (Richards \& Smith 2002), but more pertinently, governance is about interaction between stakeholders and processes as well as how power and responsibilities are exercised. Governance makes provision on how institutional decisions are taken, and how communities and other relevant stakeholders are allowed to participate in such decision-making. Bafokuzaara (2008:1) refers to governance as an exercise of political, administrative and, managerial power and authority whilst rendering public services in a manner that is legitimate, accountable, transparent, efficient and equitable. Olum (2014:606) defines good governance as one whereby the civil society and the private sector are included in the management of public affairs. In essence, a good governance system encourages its citizens to actively participate in policy formulation, implementation and analysis, amongst other activities of government. Munzhedzi and Makwembere (2019) postulate that governance is the desired manner of conduct by public institutions in the management of public resources and matters. Graham, Amos and Plumptre (2003) declare that governance is essentially about interface between structures, processes and traditions with the purpose of taking decisions, ensuring participation of stakeholders and exercising power.
The governance theory is emphatic on many principles including accountability, transparency, self-governance, collective decision-making, responsibility and consensus. Governance theory as understood by Stoker (1998) is applied in this discussion to have an adequate understanding of the application of the governance principles in the management of the COVID-19 pandemic in South Africa. Stoker (1998) claims that the theory of governance makes the following provisions about governance.

\section{Actors that are drawn from and beyond government}

The governance theory as propagated by Stoker (1998) is emphatic on the involvement of the private sector and other voluntary actors in public matters such as service delivery. In essence, what is often known as the responsibility of government is shared amongst other stakeholders outside of government. These stakeholders include oppositional political parties, ward committees, trade unions, private businesses, the general public, traditional and religious leaders. Brandsen, Verschuere and Trommel (2014) are of the view that a government by its very nature involves an interactive process between government and the said multiplicity of stakeholders. However, this is not without challenges regarding decisionmaking and accountability. The involvement of the stakeholders is from the formulation of policies up to the time the policy is implemented and evaluated. Section 152 of the Constitution of the Republic of South Africa of 1996 (hereafter referred to as 1996 Constitution) makes it mandatory for all municipalities in the country to ensure the participation of relevant stakeholders and local communities within their jurisdiction. The views of local communities including other stakeholders get incorporated into the integrated development plans, municipal budgets and other municipal policy prescripts. This is not only limited to the local sphere of government but to all spheres in that the legislative prescripts are open for public input before final approval by the relevant legislature.

\section{Governance identifies the blurring of boundaries and responsibilities for tackling social and economic issues}

The governance theory contends that the provision of goods and services should not only be reserved for government institutions (Stoker 1998). Civil society and other stakeholders play a pivotal role in as far as tackling social and economic challenges in the country is concerned (Marchetti 2018). The theory claims that the boundary of responsibilities between government and the private stakeholders is blurred in that the provision of services is the co-responsibility of a multiplicity of players. For example, a political head of a department (ministers or members of executive councils [MECs]) initiates a policy brief from a ruling party manifesto to administrative officials to develop a policy draft which is then sent to cabinet and parliament for approval. The reason for this is that administrative officials possess technical expertise that political heads lack, which is to draft a policy or legislation. At times there is an overlapping of roles, which may lead conflicts and reluctance. 
The same goes for the uncertainties between public and private sector stakeholders in the provision of social and economic services (Munzhedzi \& Makwembere 2019). The example in the context of South Africa during the COVID-19 lockdown is the provision of food parcels, which could be the responsibility of the Department of Social Development, municipalities, private entities or non-governmental organisations. There has been a duplication of responsibilities at times whereby some families received more than one food parcel. The assistance of small businesses and local farmers could also be a responsibility of provincial government, municipalities or private businesses like Agri-South Africa (Agri-SA).

\section{Identifies the power dependence in the relationships between institutions involved in collective action}

Stoker (1998) posits that governance theory discourages the spirit of individualism in that organisations must work together with an aim of achieving a collective vision. The achievement of institutional objectives is reliant on the institution's relationship with other institution within and outside of the government. Munzhedzi (2019) opined that government institutions should plan in an integrated manner, hence the concept of cooperative governance. Cooperative governance in the context of South Africa refers to the working together of the three spheres of government, namely national, provincial and local. Section 41 of the 1996 Constitution makes it compulsory for the local sphere of government to work with other spheres when planning their programmes and vice-versa. Van der Waldt (2018) claims that the integrated nature in municipalities means that they must work with other spheres of government, local communities, private businesses and traditional leaders. Municipalities also have to cooperate with other municipalities within and outside their districts.

\section{Governance is about autonomous self-governing networks of actors}

Governance theory postulates that even though there are a multiplicity of actors in the formulation and implementation of public policies, the actors are independent of each other (Stoker 1998). For example, traditional leaders have their own hierarchical structure within the institution of traditional leadership where they are held accountable. However, the traditional leadership has representation in both local and district councils to advise them on the needs of their people, particularly as it relates to customary matters (Van der Waldt 2018). As such these actors, including parastatals, oppositional political parties and trade unions, possess independent views regarding formulation and implementation of public policies. A practical example during the COVID-19 lockdown in South Africa is when the South African Democratic Teachers Union and other stakeholders objected to the earlier opening of schools for the safety of teachers and leaners. The Union was demanding assurances on issues such as safety and protective equipment such as masks, gloves and sanitizers. Some oppositional political parties in South Africa including the Economic Freedom Fighters (EFF) raised objections to an early opening of the economy through regulations.

\section{Governance as the capacity to get things done without the power of government to command or use its authority}

The governance theory recognises the capacity of getting things done without the sole control and directive of government (Stoker 1998). The overall objectives of government may be achieved without its playing an implementation role. According to this perspective of the theory, government's role in governance include, but is not limited to, (de)composition and coordination, collaboration and steering, as well as integration and regulation (Stoker 1998). Integrated Development Plans, Local Economic Development (LED) plans, National Strategy for the Development and Promotion of Small Businesses in South Africa and Integrated Sustainable Rural Development Strategies are some of the policy frameworks that are underpinned by the principle of collaboration and 'integratedness' amongst relevant stakeholders. Local Economic Development promotes the active participation of local businesses and other stakeholders in the creation of employment and general economic development. Private businesses, local communities and traditional leaders play a pivotal role in the formulation and implementation of these strategies. It is possible to achieve the good intentions of governance with the government only playing a regulatory role.

The provisions of the governance theory as discussed in the preceding section may, to a greater extant, have a positive effect in addressing developmental challenges including that of the COVID-19 pandemic. The involvement of relevant stakeholders as well as giving them space to operate may contribute constructively in the implementation of government policies.

\section{Application of governance principles in the management of the coronavirus disease 2019 in South Africa}

There are many principles of governance which are discussed in the succeeding section: the rule of law, public participation, transparency, accountability, decentralisation, effectiveness and efficiency.

\section{Rule of law}

Rule of law is an important element of governance in that it emphasises the protection of the individual and group rights in an unbiased manner. It encourages the establishment or existence of an independent judiciary, which guarantees equity, fairness and justice in a society. In addition to an independent judiciary, the country ought to have an impartial and incorruptible police service (Harrison 2005; Moloney 2009). Section 217 of the 1996 Constitution makes provision for equity, which means that those who were previously disadvantaged should be given more preference such as in procurement. Equity seeks to undo the imbalances 
of the past (pre-democratic South Africa) where only the minority whites qualified to do business with the government. The principle of rule of law seeks to emphasise that it is the law that rules and not the man (Woleola 2017). This assertion alludes to the fact that the law is above everyone including leaders of government. In the context of South Africa, the 1996 Constitution is considered to be supreme to all other law of the Republic. This also means that the Constitution takes precedent over any other decision of government by its leaders.

As a way of managing the COVID-19 pandemic in South Africa, the rule of law has to be observed. The regulations developed in terms of Section 27(2) of the Disaster Management Act, 2002 (Act 57 of 2002) have to be adhered to. These regulations make provision for amongst others things: movement of people, goods and traffic; closing down of industries, mines and workplaces; less attendance of funerals and church gatherings; and closing down of the country borders. Section 3 of the Disaster Management Act, 2002 (Act 57 of 2002) empowers the Minister of Cooperative Governance and Traditional Affairs to amend the Act and develop regulations with the purpose of effectively managing a national disaster. The disaster in this case is the COVID-19 pandemic, otherwise known as the coronavirus disease. The regulations bring about a change in the procurements of goods and services. Most of the goods and services are procured without following the normal processes stipulated by Public Finance Management Act, 1999 (Act 1 of 1999) and Local Government: Municipal Finance Management Act, 2003 (Act 56 of 2003) respectively. There have been many instances of inflating of price, fraud and corruption in Mpumalanga, KwaZulu-Natal and some other provinces since the lockdown in South Africa (EFF 2020). Provisions of the law including the disaster management regulations are continuously being infringed by some citizens, private sector entities and institutions of the state. Leaders in the government such as the Minister of Communications and Digital Technologies were also chastised by the President for violating the regulations (Daily Maverick 2020). Many individual citizens have also been arrested for infringing regulations in the form of drinking in public spaces, moving around during the curfew and visiting family and friends when the lockdown regulations do not allow these. The taxi industry was warned against plying taxis that were loaded to full capacity even though the regulations stipulated a maximum load of $70 \%$. Further, they started taking passengers and operating long distance taxis even though the regulations prohibited it (Sowetan Live 2020). Such conduct requires stricter enforcement of the rule of law.

\section{Public participation}

Section 152 of the 1996 Constitution makes it compulsory for municipalities in South Africa to work with local communities and community-based organisations in all their activities and programmes. This means that municipalities should involve relevant stakeholders in the integrated development planning and budgeting processes. Van der Waldt (2018) states that the policy-making process, which received considerable support and participation from communities, is likely to receive greater support during the policy implementation. This is not only limited to the local sphere of government in that national and provincial spheres still have the responsibility to do considerable consultation with members of the public in their own activities and programmes. A typical example is when the national legislature engaged the masses in pursuit of deciding on the likely amendment of section 25 of the 1996 Constitution. Public participation is actually at the core of governance theory. Section 25 talks about the right to property ownership including but not limited to land. The principle of public participation originates from the phenomenon of democracy that propagates the inclusion of citizen participation in governance processes (Helalo 2015; Thornhill 2012). The first instance in which citizens get involved is through national, provincial and local government elections. However, participation is inclusive of offering inputs in the policy process, paying of government services, particularly at the local sphere, and economic participation through creation of employment to the less privileged. Creation of employment enables those employed to be able to participate through payment of rates and taxes which by extension enable government to render goods and services (Munzhedzi 2019).

The effect of the COVID-19 pandemic on the governance processes particularly as it relates to public participation is so severe in that communities cannot actively participate in the activities and programmes of government. For example, one mechanism used to participate is through elected representatives in the national and provincial legislatures as well as municipal councils. By the end of June 2020 not all legislative mechanisms were physically functioning. Few portfolio committees have had meetings, let alone ineffective ones. More often than not technology in the form of Skype and Zoom became barriers rather than enablers to effective communication between members of the legislatures. The EFF made a submission to parliament requesting physical opening of parliament because legislative oversight is not being exercised effectively and efficiently. Their contention was that some meetings end up not taking place because of connection failures, or that there is one interruption or the other. To this effect, because of the COVID-19 pandemic there has been less functionality and operation of national and provincial parliament as well as municipal councils. This means less accountability for members of the executive at all spheres of government. Legislative oversight on how the executive has implemented the regulations including spending the budget since the lockdown has not been exercised to full capacity. The COVID-19 pandemic has in a sense brought about less public participation in the activities and programmes of government. Public gatherings like community meetings, imbizos [public meetings], large church and funeral gatherings and khoro/kgoro [meetings at the traditional leaders] are prohibited from taking place until the levels of lockdown have gone down (when this article was conceptualised, South Africa had just commenced with level three of the lockdown). 


\section{Transparency}

One of the fundamental tenets of good governance is the principle of transparency. The principle of transparency dictates that the public is informed of all relevant decisions and processes leading to those decisions. Sections 195, 215 and 217 of the 1996 Constitution also make a provision that the public decisions and processes must be transparent, particularly to those that they affect directly and indirectly (Republic of South Africa 1996). These provisions of the 1996 Constitution are emphatic on the greatness of information accessibility by the public (Helalo 2015). One of the most common ways in which transparency is ensured in public institutions is through the use of technology including social media. Technology makes it possible to view the status of a particular application or even the reasons for the rejection of another application. It becomes possible to know the progress of the application for a low-cost house (otherwise known as a Reconstruction and Development Programme [RDP] house). The public and institutions dealing with state institutions are guaranteed rights that entitle them to ask reasons why certain decisions were taken through the Promotion of Administrative Justice Act, 2000 (Act 3 of 2000) (Ambe \& Badenhorst-Weiss 2011). It is through this legislation that individuals concerned may challenge any decision taken by any public institution in the form of application for rescission of such decision which could be an appointment, promotion, demotion, transfer or dismissal.

During the COVID-19 pandemic environment, the public procurement processes have not been as transparent as they should. Lack of transparency may negatively contribute towards fraud and corruption in public institutions including in procurement (Munzhedzi 2016). It is through transparency in public institution where anomalies are detected, reported and corrected. Those who are charged with the responsibility of taking government decisions are more likely to act better if the processes are transparent to those involved. Most of the wrong actions including bribes, embezzlement and corruptions are often exercised in the far-flung areas where the public is not scrutinising such actions. Many corrupt practices which are alleged to have taken place during the lockdown in South Africa have been reported by the media and many other political parties (EFF 2020). Allegations about such corrupt practices took place during the procurement of protective equipment and the construction of shelters for the homeless. This is because of the manipulation of legislative prescripts, which allows for such procurement without advertisement particularly in urgent situations like that of the COVID-19 pandemic.

\section{Accountability}

It is argued that public accountability goes beyond the participation and interaction of citizens in government activities and programmes, and the answerability of leaders for their actions to the relevant structures. Moeti (ed. 2014) refers to accountability as an obligation to answer to a higher authority with regard to its authorisation and resource allocation. However, it is misconstruing to limit accountability to financial accountability (Van der Nest, Thornhill \& De Jager 2008). A manager gives an account to his seniors not only for the budget allocated, but also for the regular decisions taken about policy, personnel, procedural and control matters. Accounting in the context of public office also has to do with answering on the progress, performance, failures, successes and actual versus targeted performances (Ababio 2007:5; Munzhedzi 2014:703). The 1996 Constitution has introduced measures, which enable public officials and institutions to account for their actions. Such mechanisms include parliament, public protector, auditor general and judicial institutions. Members of the executive including the president and his ministers at the national government and the premier with their MECs account to national parliament and provincial legislatures, respectively. The auditor general also audits books of all state institutions with a purpose of identifying deviations and corrective measures. Corrective measures may include paying back stolen monies, demotion, paying a fine or getting fired for contravention of the relevant legislations like the Public Finance Management Act, 1999 (Act 1 of 1999).

Public accountability plays a critical role in as far as good governance is concerned. In the context of COVID-19, those who are charged with the responsibility to procure protective equipment must be held accountable for the budget, processes followed in procurement, nomination of food parcels beneficiaries and specific decisions regarding the management of COVID-19 in the country. It is through public accountability that deviations and anomalies are likely to be identified and corrected accordingly (Thornhill 2012). Those who suspect any maladministration and improper action on the part of state officials have a right to report such matters to the Public Protector and other relevant state institutions. The Public Protector may investigate, make a finding and pronounce a remedial action commensurate with the alleged misconduct. However, oppositional political parties like the EFF have reported that 'some councillors' of the ruling party in South Africa were seen donating food parcels to members of their political organisation as well as their families (EFF 2020). Such allegations were also reported in KwaZulu-Natal with regard to the procurement of blankets for the homeless persons. The EFF has pronounced that the state is likely not to take action against the perpetrators of such corrupt practices. They based their suspicion on the many cases where leaders of the ruling party were not adequately prosecuted or at least investigated in cases such as the Venda Building Society Mutual bank (VBS Mutual Bank) and Bosasa (EFF 2020).

\section{Decentralisation}

Governance theory as discussed above is against the notion of centralisation of powers at a national entity. One of the most important components of good governance is decentralisation of decision-making powers and authority, a contingency that includes the powers to appoint, dismiss, promote, demote, discipline and transfer officials (Ncholo 2000:89-90). 
The Public Finance Management Act, 1999 (Act 1 of 1999) and Local Government: Municipal Finance Management Act, 2003 (Act 56 of 2003) respectively confers financial management powers and authority to the accounting officers who are the administrative heads of public and municipal entities. Accounting officers report to the director general in national and provincial departments, whilst in the municipalities they report to the municipal managers. In case of other public and municipal entities such as Eskom, Transnet and Joburg Power, an accounting officer is the chief executive officer because they possess the administrative powers even whilst they report to boards or municipal councils. However, the accounting officers may delegate some of the powers they possess to other members of the administrative constituents, or the divisional managers for effective and efficient departmental operation. Munzhedzi (2020) posits that there is a provision in the two mentioned policy frameworks for devolution of power and authority to departmental managers who otherwise had limited powers. In the context of a COVID-19 environment, the South African government in its different components has a responsibility to delegate to lower-level managers so that adequate accountability, efficiency and effectiveness could be ensured. The centralisation of functions has its own negative effect on service provision (Ambe \& Badenhorst-Weiss 2011) during the COVID-19 pandemic. The State Tender Board Act, 1968 (Act 86 of 1968) was finally repealed in the democratic era with a hope of decentralising public procurement in South Africa. Decentralisation in public procurement brings with it local empowerment because contracts with the state are often awarded to local businesses where the capacity exists. Those who were previously disadvantaged are identified and empowered through relevant policy frameworks, including but not limited to Preferential Procurement Policy Framework Act, 2000 (Act 5 of 2000). Conversely, the local businesses may lack requisite capacity to render the requisite goods and services. During this time of the COVID-19 pandemic, many municipalities particularly those that are largely rural lack the skills and capacity to function optimally. Such municipalities are often exposed to corruption and maladministration because of weaker accountability mechanisms. Municipal Public Accounts Committees (MPAC) possess limited skills and capacity and lack in political will to scrutinise financial statements and municipal performance reports (Munzhedzi 2019). As a result, members of the municipal executive as well as municipal managers are not successfully held to be accountable.

\section{Effectiveness and efficiency}

The resources of the state are limited to an extent that they have to be used with care and meticulousness. This is contrary to the generally held view that resources of the state are unlimited and that it possesses capacity to do whatever the community is requesting (Thornhill 2012:112). This view supports the assertion that the state may appoint whichever number of personnel it wishes to and fund as many projects and programmes as possible. Effectiveness and efficiency are paramount if the limited resources of the state are to be spent in a sustainable manner. It is actually a provision of Section 195 of the 1996 Constitution that whenever resources of government are utilised, the principle of effectiveness and efficiency has to be applied. Mafunisa (2004:290) refers to effectiveness in the context of government as the achievement of the set goals and objectives whilst efficiency refers to such achievement with the use of the most limited resources as possible. The Auditor General of South Africa (2018) has reported that there is a massive over-expenditure regarding the allocated budget without following due process. In essence, the budget that is approved through the legislative process is no longer used as a guide regarding financial expenditure.

The application of effectiveness and efficiency during the achievement of developmental local government mandates cannot be overemphasised during the COVID-19 pandemic in South Africa. This means that the provision of all protective equipment including masks, gloves and sanitisers should be undertaken with effectiveness and efficiency. This should not only be limited to protective equipment but also to all necessary assets that are needed the most during this COVID-19 pandemic era such as water tankers, fumigating and sanitising equipment. Such must not only be provided on time but within the most limited financial resources.

All these principles of governance discussed above are necessary for the effective and efficient implementation of government programmes and policies. Like many challenges of government, the COVID-19 pandemic requires multiplicity of stakeholders to participate in finding a lasting solution. As discussed, affected communities, communitybased organisations, private sector entities and traditional and religious leaders have a paramount role to play to ensure that the pandemic is managed adequately. Governance theory also postulates that the government cannot be the sole performer in dealing with socio-economic challenges of government. Implementation of government policies including lockdown regulations must be implemented effectively and efficiently.

\section{Regulations of the Disaster Management Act, 2002 (Act 57 of 2002)}

Regulations were issued on 17 March 2020 in terms of section 27 (2) of the Disaster Management Act, 2002 (Act 57 of 2002) with the purpose of alleviating, containing and minimising the effect of a disaster (Republic of South Africa 2002). The disaster in this case is the COVID-19 disease which was later declared a pandemic by the WHO. The regulations mandated the Department of Defence, for the duration of the declared national state of disaster, to mobilise available resources and ensure the delivery of essential services so that the spread of COVID-19 could be minimised. Public gatherings were also prohibited with the sole purpose of limiting the spread of the virus. Schools were closed for a considerable period and visiting other places including churches and places of entertainment were also forbidden as a measure to contain the spread. The sale and transportation of liquor was also 
banned. However, some of these prohibitions were lifted with the introduction of subsequent phases of the lockdown.

The regulations make provision for emergency procurement of goods and services, which are applicable in terms of Section 76 of the Public Finance Management Act, 1999 (Act 1 of 1999) and Municipal Finance Management Act, 2003 (Act 56 of 2003) respectively. The said provision of the regulations basically relaxes the open bidding processes, which are deemed long and cumbersome, and introduced a closed bidding process. Albeit short, the closed bidding option does not mean that service providers are chosen without following due process. Closed bidding means that a selected number of service providers are selected from the database of the department or municipality to quote a competitive amount for final selection. A service provider cannot just be chosen with exorbitant amounts that have been inflated like what has been the case with personal protective equipment (PPE) contracts worth billions (Munzhedzi \& Phago 2020). There were many instances of price inflation, fraud and corruption in Mpumalanga, KwaZulu-Natal and some other provinces (EFF 2020). The issue is not the legislation but the application of it in many instances. The argument in this article is that these policies are not the problem, but the application of the policies is. The subsequent section of the article offers lessons for the future.

\section{Lessons for the future}

It has been conversed in the preceding sections that not all of these principles of governance are implemented the way advocated for by the governance theory. Many government institutions are lacking insofar as implementation of the provisions of governance principles in the management of the COVID-19 pandemic in South Africa. To this end, the ensuing section points out lessons for the future in as far as the management of pandemics is concerned:

- Stricter enforcement of polices: the analysis has alluded to the fact that policies such as Public Finance Management Act, 1999 (Act 1 of 1999) and Local Government: Municipal Finance Management Act, 2003 (Act 56 of 2003) are not adequately adhered to. These two policies specifically outline processes to be followed when government goods and services are procured. The policies even cater for the instances where general open bidding process may not be followed. It therefore means that no justification exists for not following due process because the policies cater for such instances of limited bidding process. Limited bidding refers to instances where only a few service providers are approached for quotation often because of the time factor. More often than not, government institutions appoint service providers without following due process of either open or limited bidding. Justification should exist and be stated for not following open bidding. Limited bidding is a process as well and is not about selecting a service provider offering services at an inflated price. These legislations including Section 217 of the 1996 Constitution also make provision of fairness in public procurement. Law enforcement officials should enforce the law to ensure compliance at all times.

- Involvement of stakeholders: relevant stakeholders including but not limited to affected communities, trade unions, oppositional political parties, religious leaders and academics should be involved from development of regulations to general management of pandemics. These stakeholders may propose workable solutions that may beef-up those developed by government working alone. This may also circumvent situations where government is taken to court as it has been the case in South Africa. There have been numerous cases where the government has been taken to court, including instances where the government was ordered by the court of law to allow the sale of products for the care of babies when lockdown restricted the sale of many other things in country.

- Government should create an enabling environment for other actors. As provided for by the governance theory discussed above, government should create space for other actors outside of government to offer their contribution and expertise. There are activities which can better be performed by the private sector or even community-based organisations.

The lessons discussed in the preceding paragraphs would offer an advancement in the management of future pandemics. It is paramount that all spheres of government as well as state-owned institutions adequately apply good governance principles in the management of these pandemics. The compliance with these principles is critical to ensure that the rule of law is observed, relevant stakeholders are involved, decision-making is decentralised, those delegated with resources and authority are accountable and that the implementation of policies is undertaken effectively and efficiently.

\section{Conclusion}

Governance as claimed by the governance theory is indeed necessary for the effective and efficient management of resources and programmes in both the public and the private sectors. Governance advocates for inclusion of relevant stakeholders in the management of government programmes and activities. For all spheres of government to adequately manage COVID-19 and all other future pandemics in South Africa, all governance principles discussed in this article have to be implemented. In all activities that are undertaken in the course of managing the pandemics, the rule of law has to be observed. As revealed in the preceding sections of this article, it cannot be overemphasised that all policies including the lockdown regulations must be enforced and adhered to by all concerned. Those who are charged with the responsibility to enforce rules and to manage state resources must be held accountable so that deviations may be detected early enough. Corrective measures should be developed as soon as deviations and anomalies are identified. Equally important is that the available resources and programmes should be 
managed in a decentralised manner. Decentralisation has many beneficial rewards for government including the fact that those in junior positions are empowered to take delegated administrative decisions. To this end, all those who are empowered with some form of authority would then in turn be accountable to a higher authority.

\section{Acknowledgements Competing interests}

The author declares that he has no financial or personal relationships that may have inappropriately influenced him in the writing of this research article.

\section{Author's contribution}

P.H.M. is the sole author of this research article.

\section{Ethical consideration}

This article followed all ethical standards for research without direct contact with human or animal subjects.

\section{Funding information}

The research received no specific grant from any funding agency in the public, commercial or not-for-profit sectors.

\section{Data availability}

Data sharing is not applicable to this article as no new data were created or analysed in this study.

\section{Disclaimer}

The views and opinions expressed in this article are those of the author and do not necessarily reflect the official policy or position of any affiliated agency of the author.

\section{References}

Ababio, E., 2007, 'Bloodhounds on municipal financial management: What goes awry?', Journal of Public Administration 42(5), 3-14.

Ambe, I.M. \& Badenhorst-Weiss, J.A., 2011, 'An exploration of public sector supply chains with specific reference to the South African situation', Journal of Public Administration 46(3), 1100-1115.

Auditor General of South Africa, 2018, General report on the local government audit outcomes, AGSA, Pretoria.

Bafokuzaara, A.M.T., 2008, 'Strengthening public accountability and governance in East Africa: Uganda's experience', paper presented at a regional forum on strengthening public accountability and governance in East Africa, Arusha, 20-21 August.

Brandsen, T., Verschuere, B. \& Trommel, W., 2014, 'Manufacturing civil society: An introduction', in T. Brandsen, B. Verschuere \& W. Trommel (eds.), Manufacturing civil society: Principles, practices and effects, pp. 1-14, Palgrave Macmillan, New York, NY.

Daily Maverick, 2020, Lockdown slapdown: Stella Ndabeni-Abrahams pleads guilty fined R1 000 for breaking law, viewed 27 June 2020, from https://www. dailymaverick.co.za/article/2020-04-22-lockdown-slapdown-stella-ndabeniabrahams-pleads-guilty-fined-r1-000-for-breaking-law/\#gsc.tab=0.
Dong, L., Hu, S. \& Gao, J., 2020, 'Discovering drugs to treat coronavirus disease 2019 (COVID-19)', Drug Discoveries \& Therapeutics 14(1), 58-60. https://doi. org/10.5582/ddt.2020.01012

Economic Freedom Fighters, 2020, EFF lays corruption charges against ANC MPL for 'sending food parcels to her house', viewed 21 June 2020, from https://citizen co.za/news/south-africa/politics/2269517/eff-lays-corruption-charges-againstanc-mpl-for-sending-food-parcels-to-her-house/.

Graham, J., Amos, B. \& Plumptre, T., 2003, Governance principles for protected areas in the 21st century: A discussion paper, viewed 28 January 2021, from https:// www.files.ethz.ch/isn/122197/pa_governance2.pdf.

Harrison, G., 2005, 'The World Bank, governance and theories of political action in Africa', British Journal of Politics and International Relations 7(2), 240-260. https://doi.org/10.1111/j.1467-856X.2005.00175.x

Helalo, T., 2015, 'An evaluation of good governance and service delivery at subnational levels in Namibia: The case of the Oshana region', Unpublished doctoral national levels in Namibia: The case
thesis, University of South Africa.

Khalil-Babatunde, M., 2014, From non-interference to good governance: Shifting perspectives on development in Africa, South African Institute of International Affairs, Braamfontein.

Mafunisa, M.J., 2004, 'Measuring efficiency and effectiveness in local government in South Africa', Journal of Public Administration 39(2), 290-301.

Marchetti, R., 2018, 'Dynamics of interaction between governments and civil society organisations', in R. Machetti (ed.), Government-NGO relationships in Africa, Asia, Europe and MENA, pp. 1-21, Routledge, New York, NY.

Matshabaphala, M.D.J., 2015, 'Leadership and good governance in the public service: Lessons from African philosophy', Journal of Public Administration 50(3), 496-504.

Moeti, K.B. (ed.), 2014, Public finance fundamentals, 2nd edn., Juta, Cape Town.

Moloney, K., 2009, 'Public administration and governance: A sector-level analysis of World Bank aid', International Review of Administrative Sciences 75(4), 609-627. https://doi.org/10.1177/0020852309349432

Munzhedzi, P.H., 2014, 'The national government's intervention in the provincial government: A case of Limpopo', Mediterranean Journal of Social Sciences 5(20), 699-704. https://doi.org/10.5901/mjss.2014.v5n20p699

Munzhedzi, P.H., 2016, 'South African public sector procurement and corruption: Inseparable twins?', Journal of Transport and Supply Management 10(1), 1-8. https://doi.org/10.4102/jtscm.v10i1.197

Munzhedzi, P.H., 2019, 'An evaluation of the development and implementation of integrated development planning process for municipalities in the Limpopo province', Unpublished doctoral thesis, University of KwaZulu-Natal.

Munzhedzi, P.H., 2020, 'An evaluation of the application of the new public management principles in the South African municipalities', Journal of Public Affairs 2132, 1-8. https://doi.org/10.1002/pa.2132

Munzhedzi, P.H. \& Makwembere, S., 2019, 'Good governance as a solution to local economic development challenges in South African municipalities', Journal of Public Administration 54(4-1), 659-676.

Munzhedzi, P.H. \& Phago, K., 2020, 'Necessitating a Germane developmental local government agenda in South Africa: A post COVID-19 contemplation', African Journal of Governance and Development 9(1.1), 181-199.

Ncholo, P., 2000, 'Reforming the public service in South Africa: A policy framework', Public Administration and Development 20(2), 87-102. https://doi.org/10.1002/1099162X(200005)20:2\%3C87::AID-PAD117\%3E3.0.CO;2-H

Olum, Y., 2014, 'Public accountability and good governance in Uganda's public sector', Journal of Public Administration 49(2.1), 603-621.

Republic of South Africa, 1996, Constitution of the Republic of South Africa, 1996, Government Printer, Pretoria.

Republic of South Africa, 2002, Disaster Management Act, 2002 (Act 57 of 2002), Government Printer, Pretoria.

Richards, D. \& Smith, M., 2002, Governance and public policy, Oxford University Press, Oxford.

Sowetan Live, 2020, Taxis continue with full capacity loading, viewed 30 June 2020, from https://www.sowetanlive.co.za/news/south-africa/2020-07-01-taxiscontinue-with-full-capacity-loading/.

Stoker, G., 1998, 'Governance as theory: Five propositions', International Social Science Journal 50(155), 17-28. https://doi.org/10.1111/1468-2451.00106

Thornhill, C., 2012, JJN Cloete's South African public administration and management, Van Schaik, Pretoria.

Van der Nest, D.P., Thornhill, C. \& De Jager, J., 2008, 'Audit committees and accountability in the South African public sector', Journal of Public Administration 43(4), 545-557.

Van der Waldt, G., 2018, Municipal management: Serving the people, 3rd edn., Juta, Cape Town.

Woleola, J.E., 2017, 'Good governance theory and the quest for good governance in Nigeria', International Journal of Humanities and Social Science 7(5), 154-161.

World Health Organization, 2020, Infection prevention and control during health care when COVID-19 is suspected, WHO, Geneva. 